\title{
10 After the war
}

\begin{abstract}
Upon liberation in May 1945, the priority for the very few Jewish survivors was to find out what had happened to their family and friends and those who did not return. For many, it took several years before they received official confirmation that they had to be assumed dead, that they had probably been murdered at a certain camp or place, on an assumed date. Many distressing stories are documented in the Red Cross War Archive. Hijme and Emilie Stoffels were honoured by the Yad Vashem award in 1968, Wim and Dien van Straten in 1971. So were many others who tried to save people from persecution and murder. The three Germans who were most directly involved with the liquidation of the orphanage served long prison terms after commuted death sentences. The commandant of Westerbork, Gemmeker, came off very lightly; he served less than six years. Of the three Dutch policemen who carried the heaviest responsibility for arresting Jews in Leiden and sending them to their death, Adrianus Biesheuvel served nine years in prison. De Groot was shot dead by the Dutch resistance in 1944. Their boss, Steven van Musscher, escaped to Germany and was never tried.
\end{abstract}

Keywords: Red Cross War Archive, displaced and missing persons, orphans, half-orphans, custody issues, Yad Vashem, Righteous among the Nations, post-war tribunals, Dutch police, collaboration, resistance

There were many regions and cities in Europe which were devastated by the war, including of course in Germany itself. The western part of the Netherlands, densely populated and the economic heartland with the cities of Amsterdam, The Hague, Rotterdam and Utrecht, was in particularly bad shape in May 1945. Following the invasion in Normandy on $6^{\text {th }}$ June 1944, and the difficult breakout from the bridgeheads later that month, the Allies ${ }^{1}$ made surprisingly rapid progress. Paris was liberated on $25^{\text {th }}$ August 1944, Brussels on $4^{\text {th }}$ September, a mere eleven and twelve and a half weeks after the landings in Normandy. Hope ran high in the Netherlands that the war would be over before Christmas 1944. But the northward

1 That is: the Western Allies, not to forget the advances made, at terrible cost, by the Soviet armies.

Focke, Jaap W., Machseh Lajesoumim: A Jewish Orphanage in the City of Leiden, 189o-1943. Amsterdam, Amsterdam University Press 2021 DOI: 10.5117/9789463726955_CH10 
advance of the allies in September 1944 (Operation Market Garden), from Belgium into Holland across three rivers and several canals got stuck at Arnhem at the bridge across the Rhine. Thereafter, the allies pushed due east from liberated France and Belgium, into the industrial part of Germany and towards Berlin. The Netherlands north of the rivers entered a long period of eight months, with exceptionally cold conditions, serious shortages of food and fuel and widespread famine in the urban areas. German terror persisted and got worse. On $1^{\text {st }}$ and $2^{\text {nd }}$ October 1944 the German army took revenge for an attack on a car with Wehrmacht officers in the small village of Putten by executing seven people, burning houses, and carrying off 659 men and boys, almost the entire male population of Putten of sixteen years and older, to the Amersfoort concentration camp. From there, 601 were deported to concentration camps in Germany; $55^{2}$ were killed by attrition. Hardly a day passed ${ }^{2}$ without people being executed or just shot dead somewhere in the occupied part of the Netherlands, often in groups of 5 to 20, as reprisals for anti-German activity. On $8^{\text {th }}$ March 1945 the Germans took revenge for an attack on an SD car which (unknown to the attackers) carried Hanns Albin Rauter, the chief of all German (and de facto Dutch) police forces in the Netherlands, who was injured. In total, the Germans executed 278 people that day: 177 men near the site of the attack, and 161 in different groups ${ }^{3}$ throughout the country. Much of the infrastructure was destroyed, and whatever could be dismantled was carried off to Germany. Holland was liberated after the fall of Berlin $\left(2^{\text {nd }}\right.$ May $)$ and the surrender of the remaining German armies in Holland, Denmark and north-east Germany on $4^{\text {th }} / 5^{\text {th }}$ May 1945. It took some fifteen years and significant assistance from the US Marshall Plan before it was to some degree back on its feet.

It is therefore not altogether surprising that during the first ten to fifteen years after 1945 the country was almost exclusively focused on the personal experiences of each individual, restoring one's livelihood, and economic recovery, with little attention (at least by today's standards) to the travails of the survivors of the death camps, or those coming back from concentration camps, prisons, or military operations. Interest in the war, or at least the willingness to talk about it, was low. Ian Buruma, the author of "Year zero: A history of 1945" (2013), describes his father's post-war experiences, back in his fraternity at the University of Utrecht in September 1945:

There may have been Jewish students among [us] who had been hiding for years under the floorboards of houses belonging to brave gentiles prepared to risk their necks. But my father does not remember anyone being especially bothered about 
such things; no one was interested in personal stories, Jewish or otherwise; they all had personal stories, often unpleasant.

For liberated Europe, the year 1945 was the start of a new era amidst chaos and confusion and dominated by "trauma, revenge, regrets, the desire to forget, the need to remember" (ibidem: quote by D. Sassoon). People wanted to get back to normal, to how it was before the war. But the world had changed and did not allow it, resulting in new conflicts such as colonial wars or internal strife.

There was little coordinated effort from the Dutch government to go out and bring the survivors home in 1944-1945. Jules Schelvis, one of the eighteen Dutch survivors of Sobibor, describes how he got home via Vaihingen, by train and truck, sleeping in cold cloister corridors, his elation standing on Dutch soil again at the border, and the terrible anti-climax when he finally reached Amsterdam (Schelvis, 2007a). Non-Jewish surviving victims of the Nazis were not treated any better. Pim Boellaard, an early resistance fighter who was caught and who survived Natzweiler (Struthof) ${ }^{4}$ and Dachau, also managed to get back to Holland on his own. But he was a much stronger person than many of his fellow survivors, some of whom could hardly stand on their feet. When he realized that the government was making little effort to bring the remaining Dutch prisoners back from Dachau, he organized his own private car column to bring them home (with the support of Prince Bernhard) (Withuis, 2013). It has been considered a "scandal" (Bossenbroek, 2001, p. 112), given the fact that Belgian as well as French officers arrived at Dachau within days of its liberation on $29^{\text {th }}$ April 1945 to organize repatriation of their countrymen. In 2000 the Dutch government apologized for the "cold reception" for the survivors. But the massive "SOTO" study which had been commissioned (ibidem) suggests that the extremely negative view about the post-war reception requires some qualification. Views expressed by individual stories are not always supported by archival documentation, and the notion that the Dutch government displayed a callous disinterest is not sustained, even if there were serious lapses in the organization. Bossenbroek and others also point out that the post-war society cannot be judged against norms and standard of the 1980s, when Holland had become a welfare state with government being held responsible for every "sorrow and misery" of its citizens. The problems facing the returning survivors were seen at the time as facing the society as a whole, while caring for individuals was left - as

4 Natzweiler or Strutthof, in the French Alsace (not to be confused with Stuthoff, near Danzig, where Paula Jacobsohn was killed), was a Nacht und Nebel camp, where the Nazis kept resistance fighters whom they wanted to disappear without trace. Boellaard found conditions in Natzweiler to be much worse than in Dachau. 
it was before the war - to each of the "pillars" or categories ${ }^{5}$ involved. But the Jewish community which could have taken care of the few thousand survivors had been almost completely wiped out, while the government did not wish to single them out or discriminate between Jews and other victims of the war. It is easy to understand the disappointment, frustration, anger and bitterness of survivors who had to fight to retrieve their stolen property or the house they lived in before deportation, who were presented with outstanding property - and council tax bills for periods after their deportation or charged for assistance received during their escape.

Another, deeper problem facing the Jewish survivors was that they were considered "the lucky ones" who had little reason to complain. The wartime experiences were expected to wear off with time. Most people, initially including many survivors themselves, did not realize how intensely the trauma of the Holocaust and having lost entire families was going to affect them, and even their post-war children, in later years. Psychiatrists were among the first to warn that they needed help, and recognition, coining the concept of the concentration camp syndrome (or KZ syndrome, on account of the German term Konzentrationslager), which eventually also covered survivors who had not gone through the camps and their descendants. A few years after liberation, many Jewish survivors decided to leave Holland, indeed Europe, for good. They were not alone: between 1947 and 1970 half a million ${ }^{6}$ Dutchmen (some $5 \%$ of the population) left Europe, motivated by economic duress or fear for a third world war, and encouraged by the Dutch government, to countries like the USA and Canada, South Africa, or Australia and New Zealand. For the few Jewish survivors, Israel was of course also an important destination. Emigration skyrocketed in 1948/1949.

Seminal books on the Holocaust in Holland were first published by Herzberg (1985), in 1950, and Presser, in 1965. But it was really Lou de Jong and his series "De Bezetting" (The Occupation) on television, then a brand-new medium, that people were confronted with the occupation outside their own immediate sphere of experience. The 21-part series, which ran from 1960 to 1965 , attracted a very large audience and had a mesmerizing effect on the Dutch, who, for the first time, were presented with a coherent view of what really happened between 1940 and 1945, including, of course, the Holocaust (or Shoah). At the same time, the trial of Adolf Eichmann in Jerusalem (1961) opened the eyes of the world for the enormity of the Shoah. It was also during these years that the first post-war generation, including the present author, was confronted with the history of the war.

5 SOTO investigated Jews, Roma and Sinti, political prisoners, resistance fighters, POWs, workers returning from forced labour, military personnel and civilians repatriated from Indonesia (the former Dutch East Indies).

6 Government data. Not including some 200,00o people who emigrated to countries within Europe. 
But, back in 1945, Jewish survivors were generally focused on one question only: Where are our children, our parents, grandparents, uncles, nephews, cousins, friends, neighbours?

\subsection{Where are they? The intolerable uncertainty}

"Upon liberation in May 1945, frenzied crowds were celebrating in the streets for months." Many photos and film fragments exist to support this statement. ${ }^{7}$ But it did not apply to the few Dutch Jews who had returned from the camps, or those who had surfaced from onderduik. Rather, they were glued to a radio, or visiting Red Cross offices, to find out where their family member and friends were. Weekly radio broadcasts announced only the few people who were confirmed to be still alive. But there was, in general, no news about those - the overwhelming majority of deportees - who had not returned. It is difficult today to understand that many people still had no confirmation about the fate of their loved ones, years after the war. But the chaos in Europe was enormous in 1945, with millions of displaced persons, refugees, survivors, parents looking in vain for their children, and children who were never reunited with their parents or family, Jewish and gentiles, victors and foes. On the cover photo of Ian Buruma's book (2013) about the year 1945, a woman shows a photograph of (presumably) her son to laughing soldiers returning from the war on the remote chance that someone may recognize him and tell her what happened to him.

Legal considerations also caused delays before official statements could be issued about Jewish victims who had simply vanished from the face of the earth without leaving remains or records. For family members of persons who never returned from deportation it was of the utmost importance to receive some evidence-based confirmation of their death, and where and when they were killed, if only to relieve them from the uncertainty and allow them to deal with the loss.

Clara Adler-Braun, the mother of Lotte and Henny (Ch. 5.7), had sent letters from the USA to Leiden during the war, via the Red Cross, who probably forwarded them to the Joodse Raad until it stopped operating in 1943. As soon as she heard about the German surrender in Holland on $5^{\text {th }}$ May 1945, she sent a letter to the Red Cross (Fig. 10.1), asking how she could get in touch with Lotte and Henny. In her letter $\left(9^{\text {th }}\right.$ May 1945) Clara writes that she managed to get US entry visas for the girls in 1941, when it was too late to get them over. It is the first document of many ${ }^{8}$ spanning the period May 1945 to 1959, in which Clara, and then her son Kurt, try to establish

7 From the (otherwise excellent) young persons' TV series "13 in de oorlog" (2009).

8 Dossier. 


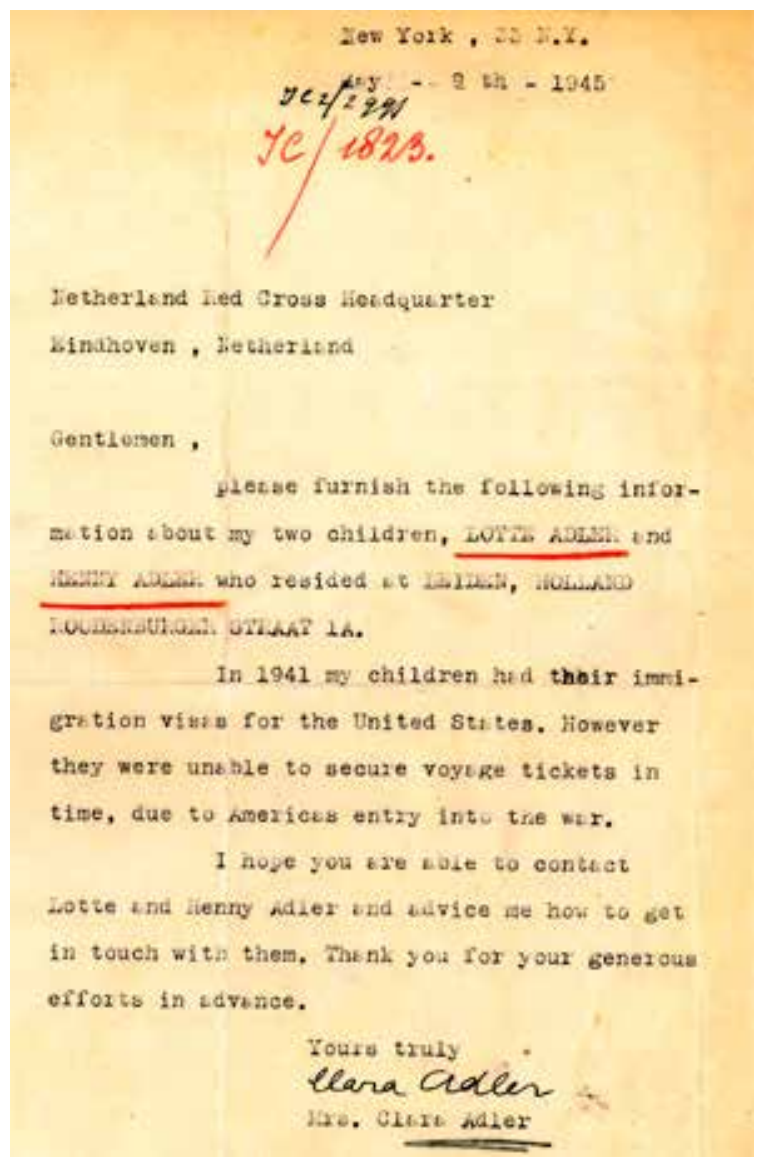

Figure 10.1: Four days after the German surrender in the Netherlands, Clara Adler wrote to the Red Cross to find out the whereabouts of Lotte and Henny. Red Cross Archives, 2017. what had happened to Lotte and Henny.

On $18^{\text {th }}$ November 1945 it is still assumed that Lotte was deported to Auschwitz. On $30^{\text {th }}$ November 1946, the Red Cross bureau in Westerbork reports to The Hague that she was deported "to the East" on $23^{\text {rd }}$ March 1943, but that at this time (one and a half years after the war!) " $n o$ further information on her is available". The Joint Distribution Committee requests the Red Cross on $18^{\text {th }}$ May 1949 to "expedite sending back the information requests [...] because family oversees are anxiously waiting for information". On $15^{\text {th }}$ August 1949, for the first time, a formal declaration is issued (Fig. 10.2) by the Red Cross about Lotte Adler:

[She] arrived in Westerbork on $19^{\text {th }}$ March 1943, [and] was deported to Sobibor on $23^{\text {rd }}$ March 1943. Taking into account the witness accounts by Sara Engel, Chaim Engel, and Ursula Stern, who survived deportation out of the more than 33,000 persons deported to this camp from Westerbork,

that practically all deported people were killed by gas asphyxiation immediately upon arrival, [...] she must be assumed to have died on or around the $26^{\text {th }}$ of March 1943.

On $14^{\text {th }}$ November 1957 the Red Cross Bureau in Germany issued a"certificate of incarceration" for Lotte to government officials in Wiesbaden, West Germany, but making the point that the document could not be used as a death certificate, and no such certificate was presented to the officials. The Red Cross in The Hague then confirms her death to the Ambtsgericht in Frankfurt. On $5^{\text {th }}$ January 1959, a notary public in California writes a letter on behalf of Kurt Adler, asking for copies of the relevant documents and certificates. He writes about Kurt's sisters Lotte and Henny "who were in hiding". The letter shows how little even close relatives know at 


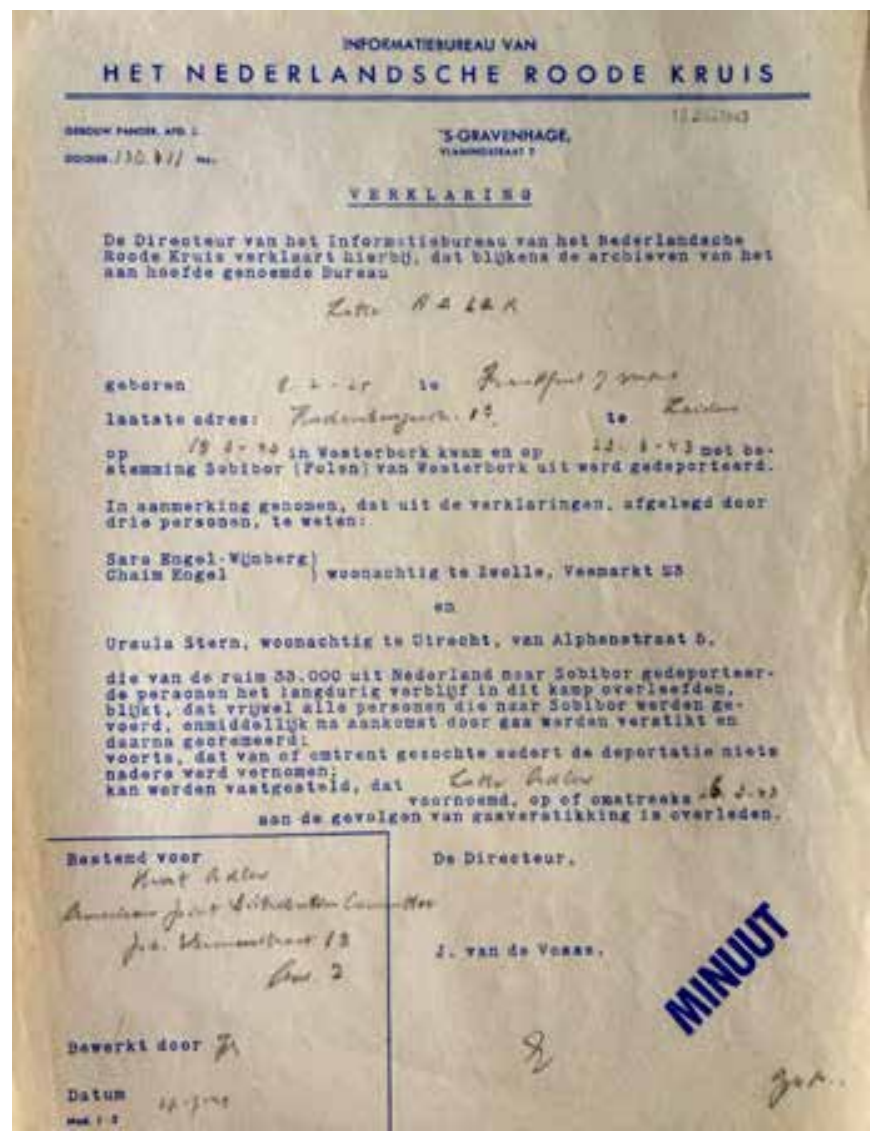

Figure 10.2: The formal death certificate for Lotte Adler, including the evidence that there was no doubt about her fate. Issued on $15^{\text {th }}$ August 1949 and referring to three witness accounts. Courtesy Red Cross, The Hague, 2017. For documents not included in the book, see the Lotte \& Henny Adler dossier.

that time about what really happened between 1940 and 1943 . With respect to the millions of victims who were murdered in the Holocaust by premeditated plan, organized and executed as if it were an industrial enterprise, it is probably fair to say that it took 15 to 20 years to get enough facts together, and the documentary evidence, to document what had happened, and how it was done.

It took decades more to digest these facts and develop a comprehensive view of the enormity of the Holocaust; not to mention attempts to understand it. That process has not been concluded to this day. 


\subsection{Reunited, but without the father}

There were 4138 children in onderduik at the end of the war (i.e. September 1944 for the southern provinces of Brabant and Limburg, May 1945 for the rest of the country), of which $345^{8}$ were Jewish (Michman et al., 1999, p. 209). Of those, 1417 children could be reunited with one or both parents, including Kurt and Helga Gottschalk, Aron Wolff, the five children Philipson (Fig. 10.3), the four children Klein (Fig. 10.4) and the children of Rebecca Franschman (the mother of Piet de Vries) and Barend Springer, for whom Stoffels had arranged onderduik.

It would seem totally self-evident today that all Jewish children who had one or two parents returning from the camps (preciously few in any case), or surfacing from onderduik, would be reunited with them at the earliest opportunity. And indeed, they all were reunited, without exception, but not without problems, fights, and sadness. Some young children had become strongly attached to their foster parents, while others never did. There were good and less-good foster parents, and the motivation of foster parents offering shelter to Jewish children varied. Aron Wolff (in 2017) could still perform the rituals which he learned when hiding (temporarily) with a Reformed Protestant family in Apeldoorn (Ch. 9.4); but it may have improved his safety, and the family as far as Ronnie remembers did not try to convert him. But some other Christian onderduik parents did. Some onderduik foster parents even argued, during the war when they probably still expected most parents to return

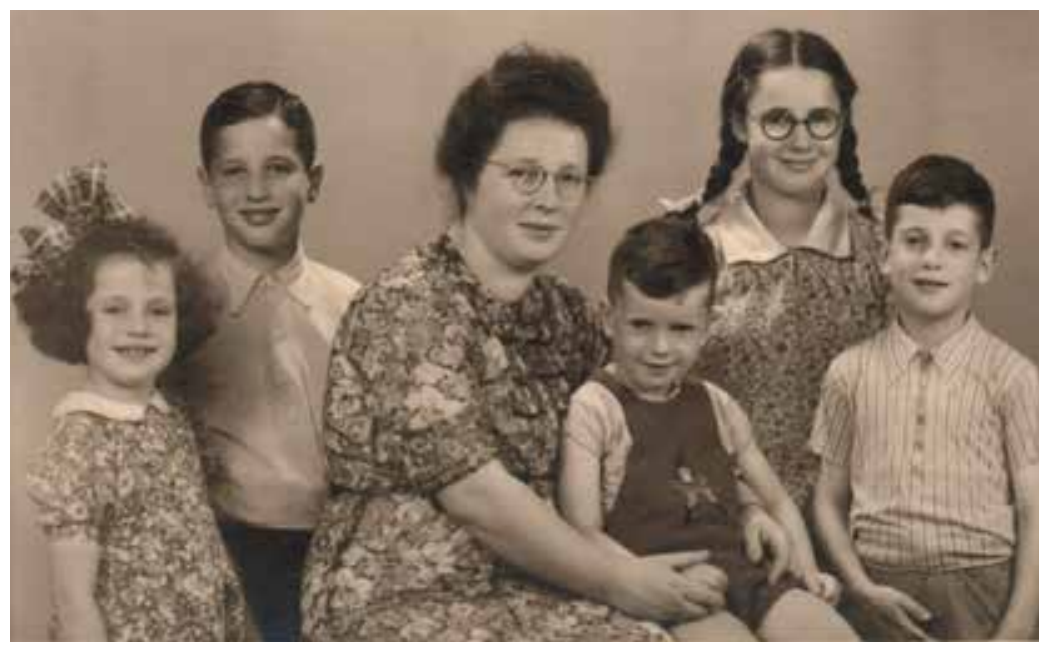

Figure 10.3: Jet Philipson-Simons with her children shortly before their emigration to Palestine, 1947. From left: Sara (19 ${ }^{\text {th }}$ September 1940), Elias ( $6^{\text {th }}$ January 1937- $6^{\text {th }}$ March 2016), Jet (20 ${ }^{\text {th }}$ March 1911-2 ${ }^{\text {nd }}$ June 1992), Menachem (13 ${ }^{\text {th }}$ October 1942), Rika (4 ${ }^{\text {th }}$ November 1935), and Jacob ( $9^{\text {th }}$ June 1938). From the Stoffels photo album. Private collection. 


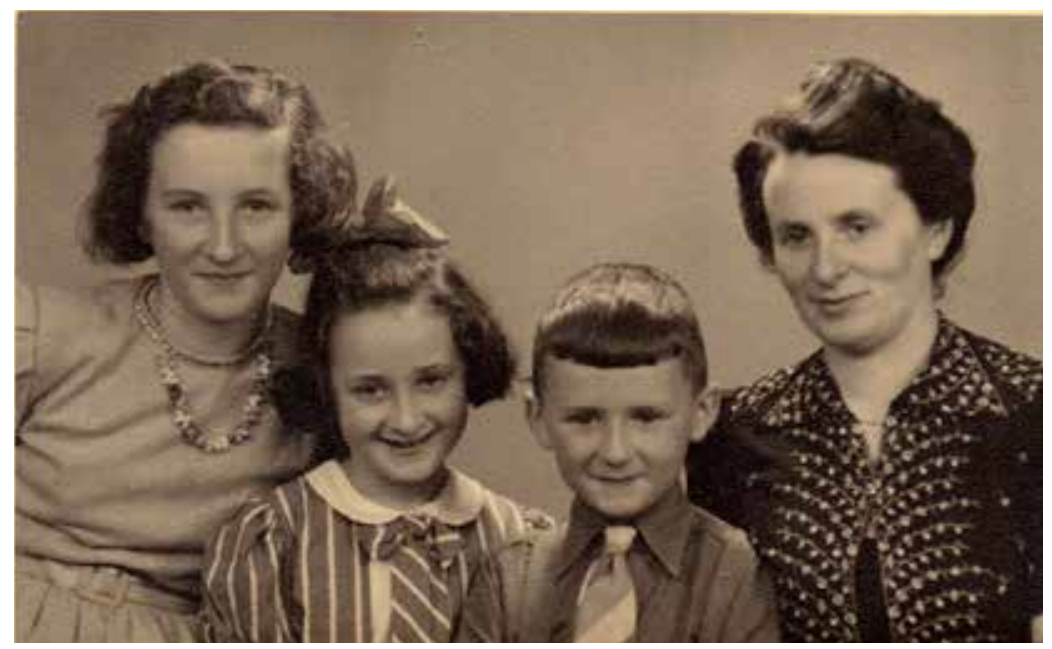

Figure 10.4: Rosa Klein-Mendel with her children, Rita, Ingrid and Ben, 1947. They moved to Florida, USA, in 1952. From the Stoffels' photo album. Private collection.

eventually, that they should not have to return the children to their parents. But ultimately all returning parents were reunited with surviving children.

The situation around the children who survived the war while their parents did not, the real orphans, was more complex, and subject to decisions by courts. Some people argued that the children should be returned to the Jewish community, small as it had become, even if the child had become fully integrated in their non-Jewish onderduik family. Others argued that the court should only consider what it believed to be the best interest of the child. Many are the heart-breaking stories where the foster parents did not want to let their onderduik child go, or the child did not want to be forcefully sent to a surviving family member they did not know.

Many children continued to visit their foster parents for many years even from Israel or the USA, including Aron Wolff and the children Klein and Philipson.

Other children experienced onderduik as a very difficult period. For many years Merlyn Frank has come to the memorial service at Leiden orphanage to talk to the students from the Erasmus College. She was only three years old when she was rescued from the train to Westerbork. She tells them how she was unable to show affection for her foster mother because she could not give up looking for her own mother, ever. Frank's book "Koosje" (1998) is not only a monument to her mother, who had the terrible courage to give her and her baby brother away to total strangers ${ }^{9}$ in

9 Members of the Utrecht student group who were present on the platform of the Utrecht railway station, where the train stopped on the way to Westerbork. There were no guards, and the family stood close to the doors. 


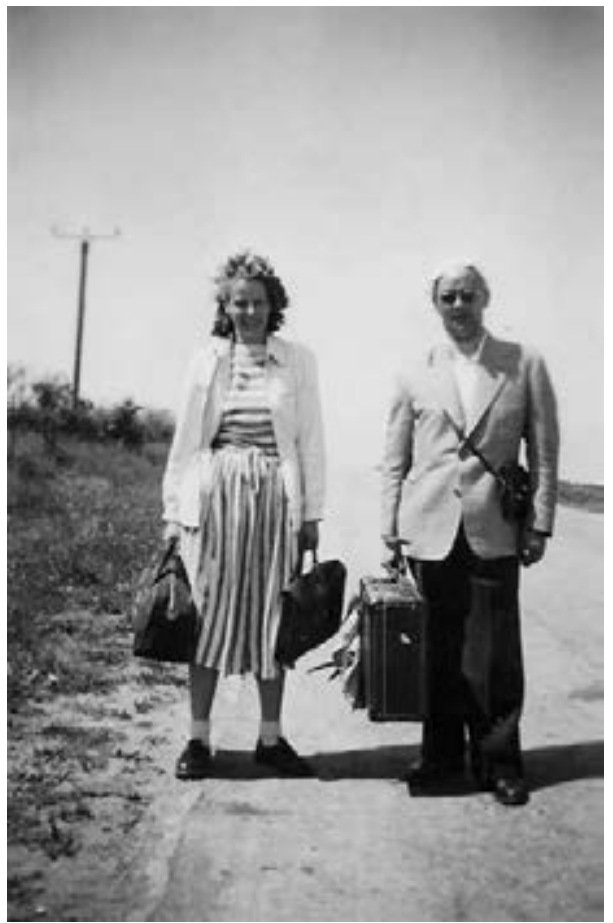

Figure 10.5: Emilie and Hijme, hitchhiking through Israel, 1949. Private collection.

a split-second decision, but probably also Merlyn's way of finally having found her.

Of those children in the Leiden orphanage who were still very young in 1943, only Mindel Färber survived the war. The other children who survived were old enough in 1945 to make their own decisions, such as Hans Kloosterman, who was thirteen in May 1940, but eighteen in May 1945. But even in his case, the reunion with his father following his release from Westerbork and the post-war period were far from easy. Hans went to Australia; as did Bram Degen. Elchanan Italie and his wife, Greet, and Jet Philipson and her children (Fig. 10.3) left for Israel. Rosie Klein and her children (Emilie's neighbours in 1941, Fig. 10.4) settled in Miami, Florida. Ben and Gerda Meijer, the other neighbours of Emilie "from the Mariënpoelstraat" started a successful dairy farm in Beit Yitzhak, Israel (Kopuit, 1974).

Hijme and Emilie visited the families Italie, Philipson and Meijer in Israel in 1949, and left a report and photographs (Fig. 10.5) of their trip. The country was still in turmoil, having barely escaped being destroyed by four invading armies. Conditions were visibly very poor, with no adequate housing, no services, no public transport. Hijme writes that it took them a day to realize that the only way for them to move around was to do what everybody else was doing: stand along the road with their suitcase and hitch-hike (Fig. 10.5). It was a new experience for Hijme, who drove around Europe in his own car before the war.

\subsection{Recognition for the righteous}

Yad Vashem was created by the Israeli parliament in 1953. Its mission included "paying tribute to the Righteous Among the Nations who risked themselves to save Jews during the Holocaust". During the first ten years, with budgetary and organizational

10 There were three families Meijer in Leiden, all originally cattle merchants from the village of Vlagtwedde, and all three had a son called Benjamin of about the same age. 

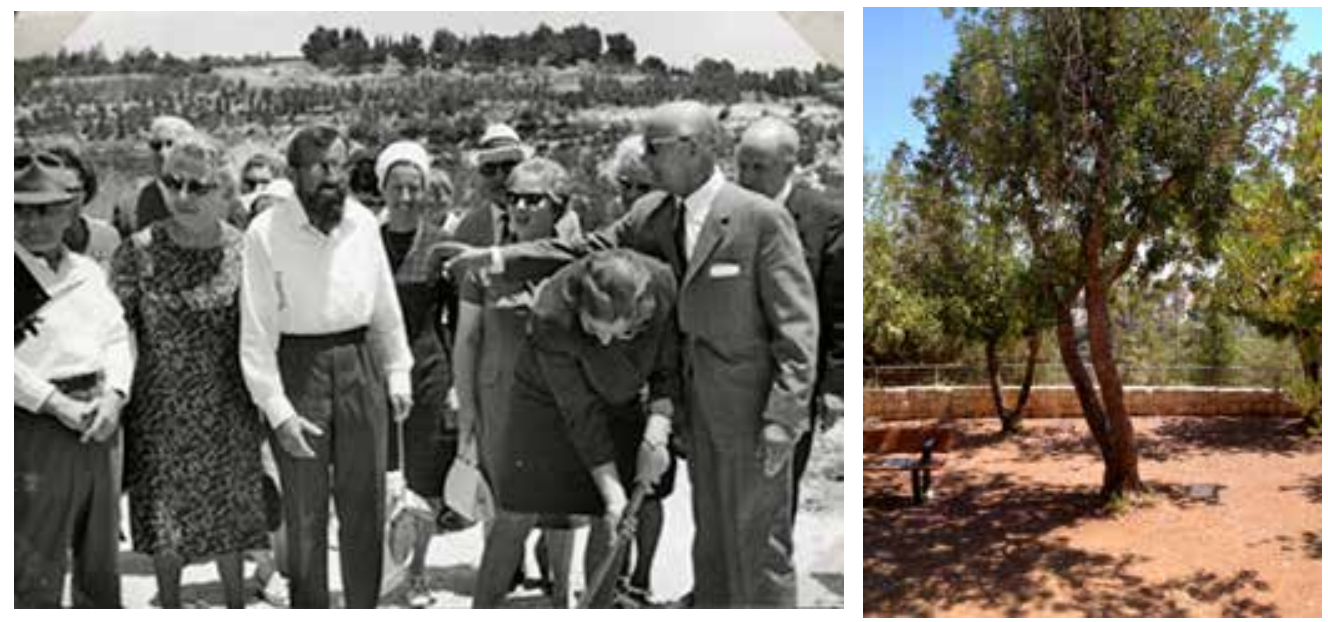

Figure 10.6: Tree-planting ceremony at Yad Vashem for Hijme and Emilie Stoffels, $7^{\text {th }}$ May 1968. In white shirt: Elchanan Italie; behind him with white headscarf: his wife, Greet. Right: The trees of Truus Wijsmuller (centre, in front) and Hijme and Emilie (behind, close to the low wall) in 2017. Photos from Stoffels' album, private collection

constraints, attention focused on data gathering, research, amassing the evidence, and - above all - recording the names of the victims (see Epilogue). The Yad Vashem website, describing the development of the "Righteous" programme, ${ }^{11}$ mentions that

the need to ceremoniously honour rescuers was raised again and again by survivors. They had not forgotten those who stood by their side during the Holocaust, maintained contact with their rescuers after the war, sent them packages and money, invited them to come to Israel, and wrote to Israeli leaders and to Yad Vashem requesting to pay tribute to those that had saved their lives.

In 1962 the first trees were planted, and in 1963 the Commission for the Designation of the Righteous was inaugurated. From the beginning, the need for a rigorous process, based on agreed guidelines and criteria, was recognized, and the commission was staffed accordingly, to include senior members of the judiciary.

It did not take long for the families Italie, Philipson and Klein to start the procedure for Hijme and Emilie Stoffels. Elchanan Italie (Ch. 9.9) wrote to Hijme (probably in early 1966) for help in getting the necessary documentation together. Hijme and Emilie rarely talked about what they did during the war (Ab van Brussel, personal communication), and to the best of my knowledge never sought public or private recognition for their actions. Responding to Elchanan's request, Emilie wrote

11 See www.yadvashem.org/yv/en/exhibitions/righteous/milestoneo3.asp. 
a shortlist of names, and Hijme put together a typed summary. On $7^{\text {th }}$ May 1968 Hijme and Emilie were honoured at Yad Vashem. A tree was planted along the Lane of the Righteous that same day (Fig. 10.6).

Hijme's summary (Stoffels \& Stoffels-van Brussel, 1967) is a rather modest account of their activities. The recovery of their private archive in 2004 revealed that Stoffels did much more during the war than what he wrote down in 1966. He provided new identities and papers to many people (Fig. 10.7), such as Sara Bromet, who received a "new pb to replace her J-stamped original" (lower part of Fig. 10.7). He added by hand the number of the counterfeit new pb: 06951. Sara's original pb (no. o6oog with J-stamp and Sperre) is shown in Figure 6.2. ${ }^{12}$ Below "Bromet" are listed Leendert van den Heuvel and Tine Heskes, the new identities of the parents of Donald de Marcas (Ch. 7.3). The cases of Hugo van de Wal (the son of Inspector van de Wal, one of Stoffels' "good" contacts in the Leiden police force [see the first line on Fig. 10.7]) and the two other boys, Johannes and Willem Arie, are quite different: they all received new but false pbs, identical in every detail to the old ones, except their birth year, which was changed to make them one or two years younger, probably to extend their status as students. On the other hand, the birth years of Koumans, Snellen and van Deenen (Fig. 10.7) were changed to make them a few years older, to prevent them being arrested and sent to Germany to do forced labour (Arbeitseinsatz). The Germans called up men based on their age. Hijme also made a false $\mathrm{pb}$ for himself, indicating he was five years older than he actually was.

It was virtually impossible to produce a perfect counterfeit Dutch pb; it contained too many sophisticated security elements (Ch. 6.2). But Stoffels had access to blank originals thanks to two contacts at the Leiden Civil Registry: Cor van Wijk and Kees Montanus. They were also able to make changes in the registries to make sure there were no discrepancies between the forged document and the records in the Town Hall. But duplicates, including a photograph, signature and fingerprint, were also stored by the National Registry, in The Hague at the Villa Kleykamp and out of reach of the resistance, so dangers remained. The records in the Villa Kleykamp were partially destroyed during a precision bombing by the Royal Air Force on $11^{\text {th }}$ April 1944. Hijme had a list of names which could be used for falsifications safely after the bombardment, but for many people it was too late.

On one of the work notes (Fig. 10.8), Hijme replies to Bep Bedak (later Bep Schaap), discussing with her details of counterfeit persoonsbewijzen in the making, using code numbers to indicate who the receiver is, and advising her to "use a real Leiden

12 Sara did not eventually need the false pb: she escaped deportation by her marriage to a non-Jewish partner. But that escape route was not yet known to exist at the time when Stoffels provided her with a new identity. 


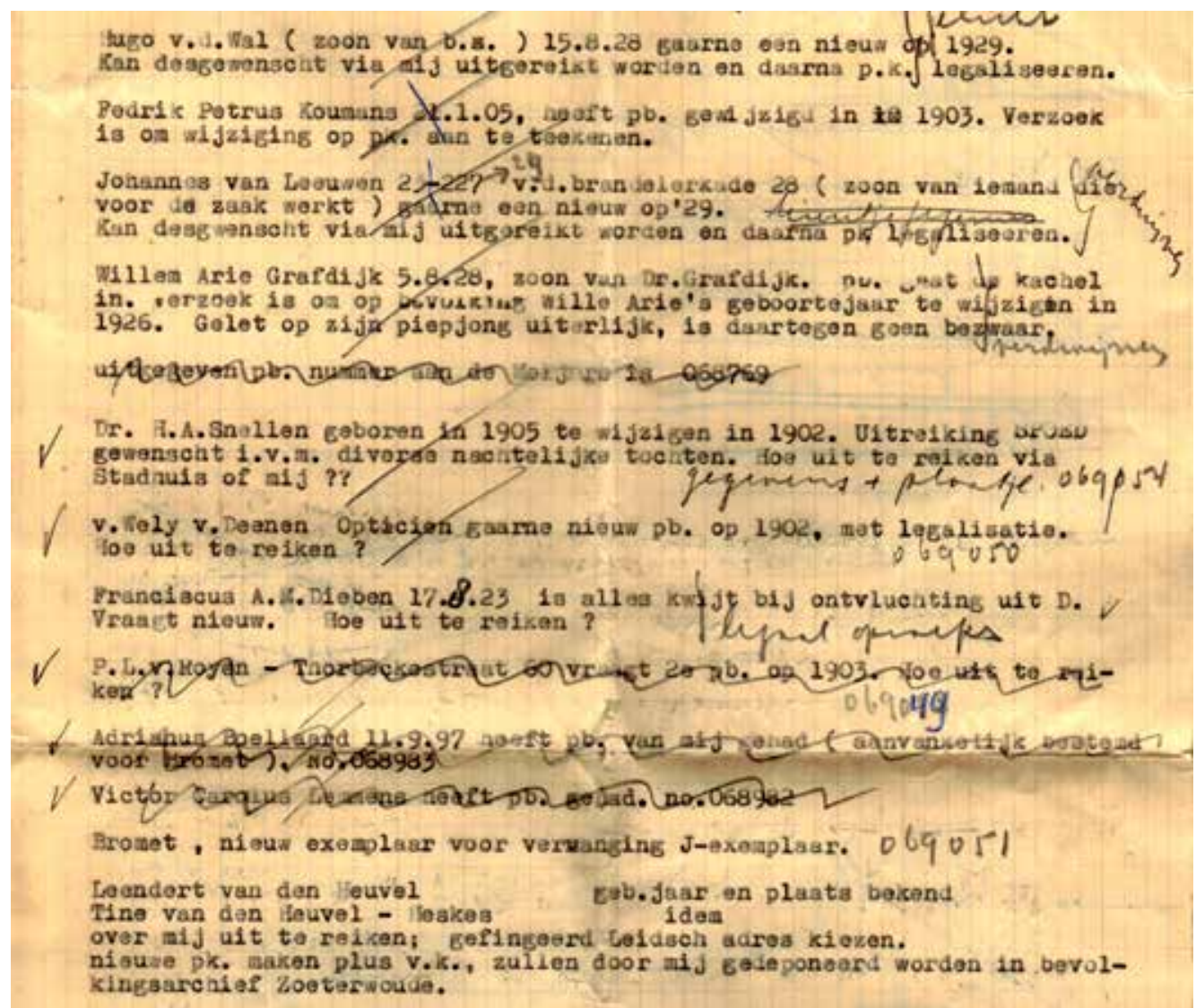

Figure 10.7: Part of a work note (probably between van Wijk and Stoffels) listing active cases of providing people with counterfeit identity papers. From the Stoffels' private archive. The handwriting is by the Stoffels. Private collection.

street name, but a non-existing house number. [...] Use a typewriter and copy the initial of the civil servant by taking any other pb issued in Leiden." He warns her not to let anybody travel; the day before the Feldgendarmerie (German police) was active in the trains, checking the pb of travellers against lists which they carried with them. If in doubt, they could arrest the person and check the papers against the above-mentioned central records.

In the same note Hijme asks Bep to give him a call first before visiting his house, because on her previous visit "Hans [Kloosterman], who knows you, has seen you and now knows you are involved; Daan [Piet] de Vries is also staying in our house. Did he see you as well?" Bep replies she will be more discreet in the future, and that Piet has not seen her that day.

Van Wijk kept track of what they did and prepared a list after the war with details of all the forgeries (van Wijk, 1946). He listed some 400 persons who received false 
Bep.

Antwoord op briefje van gisteren.

Briefie bij kennis 154. Was at gestencild p Begon met onderduiker en eindigde met Nederlander ? Dan oorspr ong bekend. Beteekent gat in dat huis een jongen is die naar $\mathrm{D}$. moest en niet gegaan is en dat adres bij. Sicherheit be-

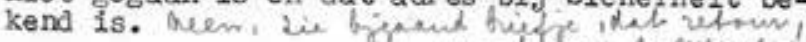

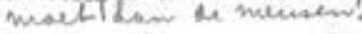

PB.van B.i.d.M. Den niet bestaand adres noemen d.w.z. wel straat doch niet bestaand huisno. Liv verandering per schriffmachine. Paraaf Ki.jk maar eens een paar Leidsche p.b.'s na. Jorde

Geblokkeerde nummers worden nog opererzocht. Laat intusschen nifmand reizen, want gisteravond was weer Feldgendarmerie in tre in met p.b. nummer en naamboek ter controle. dole twet?

Volgens juist ontvangen telefoon krijg ik waarschijniljk woensdag of Donderdag pas. Ik

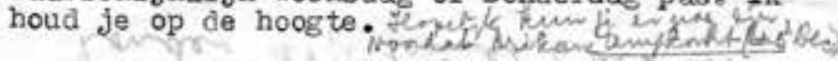

Geef nu gegevens ouden man en foto. Kosten zal

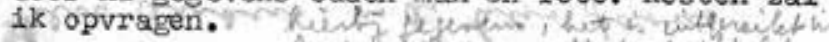

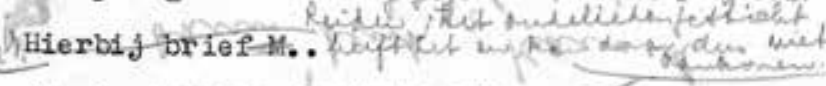

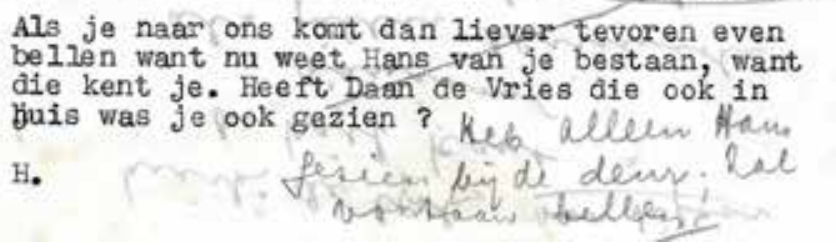

Figure 10.8: Another work note from Hijme to Bep Bedak about providing false identity papers to various people (see text). Handwritten comments are from Bep, probably late 1943. Private collection.

identity papers through himself and his colleague at the Leiden Civil Registry, Montanus, of which 124 were arranged through Stoffels. Elchanan Italie is included as no. 31 (Fig. 9.37). Cor gave Hijme the materials to fabricate the pbs himself; much of it was found in the boxes of their private archive, which was made available by the family of Emilie van Brussel in 2004 (courtesy Mr. P. de Jong). Apart from van Wijk, Montanus and Stoffels, a surprisingly large number of people were involved in the identity scam: other well-known members of the resistance such as Lex Bernard, Bep Bedak and Gerda Meijer, the people in need of help, people who knew where they should go for help, and so on. Stoffels and his wife were well known in Leiden through their respective Protestant and Catholic congregations. The parents and siblings of Emilie van Brussel were very worried at the time that they 
were taking too many risks. Work notes in their private archive such as Fig. 10.8 show that Stoffels was well aware of the risks.

The owners of these counterfeit pbs, if only the birth date was false, often continued to "walk around" in public. This type of hiding for the Germans contrasts with the classic idea of people hiding in dark spaces and never coming out, but they were onderduikers nevertheless (Siebelt, 2015).

Among the 72 Jews included in van Wijk's list is Leesha Rose, at that time Leesha Bornstein. She received the false identity Elizabeth (Lies) Bos, and subsequently became an active member of the group by arranging false papers for eighteen others. She secured Yad Vashem recognition for both van Wijk and Montanus in 1983. Her book "The tulips are red" (Rose, 1978, 1980) contains much detail about the activities around van Wijk, as well as his photograph (ibidem p. 233).

As said, the Stoffels were both recognized by Yad Vashem on $28^{\text {th }}$ April 1968. Their tree stands proudly along the Avenue of the Righteous, next to the tree for Truus Wijsmuller (Fig. 10.6). The family Philipson presented them with a photo album. Hijme died in Noordwijk on $2^{\text {nd }}$ May 1975, 67 years old. Emilie died on $5^{\text {th }}$ February 1995. Ingrid Klein flew in from the USA on the next day for the funeral, which was also attended by Elchanan Italie, Piet Krans and others who had all found a hiding place at the Stoffels' house between 1943 and 1945, or elsewhere, through their facilitation.

Dien and Wim ("Johan") van Straten were recognized by Yad Vashem ${ }^{13}$ on $22^{\text {nd }}$ June 1971 for sheltering Aron Wolff (Ch. 9.4) and at least three other Jewish onderduikers. They made several visits to Israel (Fig. 10.9), and Ronnie returned to Huizen on several occasions.

The families who sheltered the children Klein and Philipson were also recognized (details in Michman \& Flim, 2004, or the Yad Vashem website).

The Yad Vashem award is awarded on behalf of the Jewish people or the Jewish nation to non-Jewish people who contributed to the survival of Jews during the Holocaust. Beyond doubt the programme has proven itself over the decades. But it leaves unrecognized the many Jewish Dutchmen who helped to save people from persecution and those who performed other acts of resistance. Within the "small-scale history" of the Leiden orphanage I have mentioned Leesha Bornstein (Rose) in this chapter, Ralph and Jansje Litten-Serlui in Chapter 9.6, and Mirjam and Menachem Pinkhof-Waterman, Shushu Simon and others associated with Lodi Cohen in Chapter 9.7. In Leiden itself, Gerda Meijer and Bep Bedak (Schaap) were active co-workers of Stoffels before they became active outside Leiden. Last but not least, those who had the courage to go into hiding, like the families Philipson

13 See https://righteous.yadvashem.org/?search=van\%2ostraten\&searchType=righteous_only\&langu age $=$ en\&itemId $=4022534$ \&ind $=1$. 


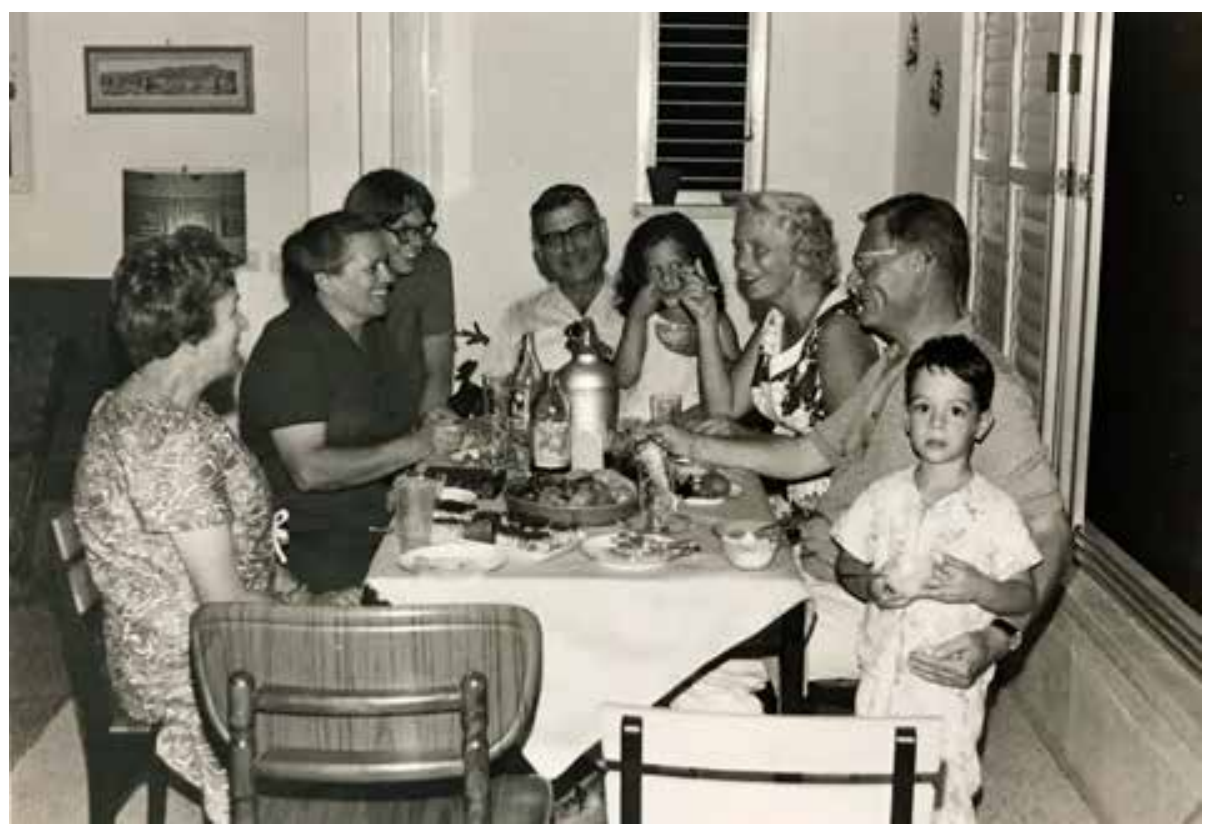

Figure 10.9: Visiting Ronnie's family in Israel, $20^{\text {th }}$ July 1971. From right: Amir (Ronnie's son), Wim ("Johan") and Dien van Straten, Mr. Alban and his daughter, Bert van Straten, Mrs. Alban, and Serlina de Paauw in the left corner. Photo, taken by Ronnie, from van Straten's report.

and Klein, and the family of Donald de Marcas, also performed important acts of resistance.

\subsection{The perpetrators: Was justice done?}

The most senior Nazis obviously carried the heaviest responsibility for the planning and execution of the Holocaust in the Netherlands, people like Seyss-Inquart (executed), Rauter (executed), SS Major General Wilhelm Harster (twelve years' imprisonment, but released in 1953), SS Major Wilhelm Zöpf (who escaped justice in the Netherlands ${ }^{14}$ ) in The Hague, or their bosses in Berlin, such as Himmler (suicide) and Eichmann (executed in Israel in 1962), to name just a few. The people shown in Figure 10.10 were the "hands-on" perpetrators in planning, coordinating,

14 Zöpf represented Eichmann's Office IV B4, the Jewish affairs and deportation bureau of the RSHA in Berlin. He was seconded to the SS in The Hague in 1941, to work under Harster. The two had known each other for a long time. Zöpf coordinated the deportation of Jews to the concentration camps in the East. He fled in 1945, but was identified in 1959 in West Germany. Germany, however, refused to extradite him. In 1967 the mood in Germany had begun to change. Both Harster and Zöpf were tried in München, convicted and sentenced to prison terms. 

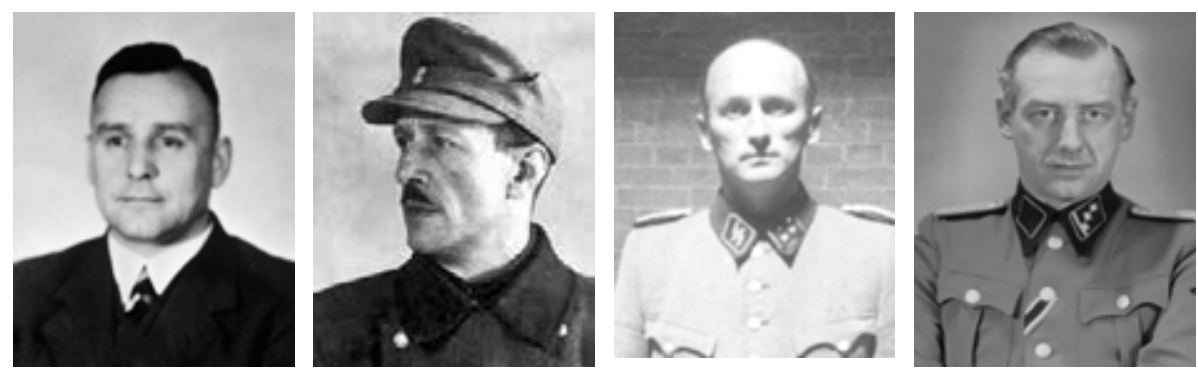

Figure 10.10: The main German perpetrators in the context of this book. Photos: NIOD and various other sources.

Franz Fischer (1901-1989) Death > Life; released 1989 $\begin{array}{ll}\text { Ferdinand aus der Fünten } & \text { Willy Lages (1901-1971) } \\ \begin{array}{ll}\text { (1909-1989) } & \text { Death }>\text { Life, Released } \\ \text { Death }>\text { Life, released } & 1966\end{array}\end{array}$ 1989
Albert K. Gemmeker (1907-1982)

Ten years, released 1951

and executing the systematic hunting down and deportation of the Dutch Jews. Fischer, Aus der Fünten, and Lages became the focus of public attention after the war when they were imprisoned in Holland.

Franz Fischer was a (Waffen)-SS-Sturmscharführer (sergeant major). He fanatically hunted down Jews in The Hague and surrounding region and was responsible for the deportation of some 13,000 Jews from The Hague. Some 12,000 of those were killed, mainly in Auschwitz and Sobibor. He was present in person in Leiden on $17^{\text {th }}$ March 1943, the day of the razzia and the ontruiming of the orphanage (Kasteleyn, 2003). His death sentence in 1950 was commuted by Queen Juliana of the Netherlands, after which he spent the rest of his life in prison in Breda. He was released in January 1989 and died the same year in his birth town of Bigge (Germany).

Ferdinand aus der Fünten was a SS-Hauptsturmführer (captain) and an executive officer in the Zentralstelle. He was the key figure in the deportation of some 50,000 Jews from Amsterdam. He personally led the brutal deportation to Auschwitz of 1000 patients from the Jewish Mental Institute in Apeldoorn on $22^{\text {nd }}$ January 1943. He was sentenced to death in 1950 but, like Fischer, he was pardoned by Queen Juliana, after which he spent the rest of his life in prison in Breda. He was released in January 1989 together with Franz Fischer and died in April of that year in Duisburg, Germany.

Willy Lages was a SS-Sturmbannführer (major); he was Aus der Fünten's superior, as head of the Zentralstelle in Amsterdam and as such responsible for the deportation and murder of more than 100,00o Jewish Dutchmen. He "visited" Werkdorp Wieringermeer in early 1941 together with Klaus Barbie, the "Butcher of Lyon", as a preliminary to the deportation and murder of the Werkdorp Palestine Pioneers. He was also responsible for the capture, torture and execution of Dutch resistance 

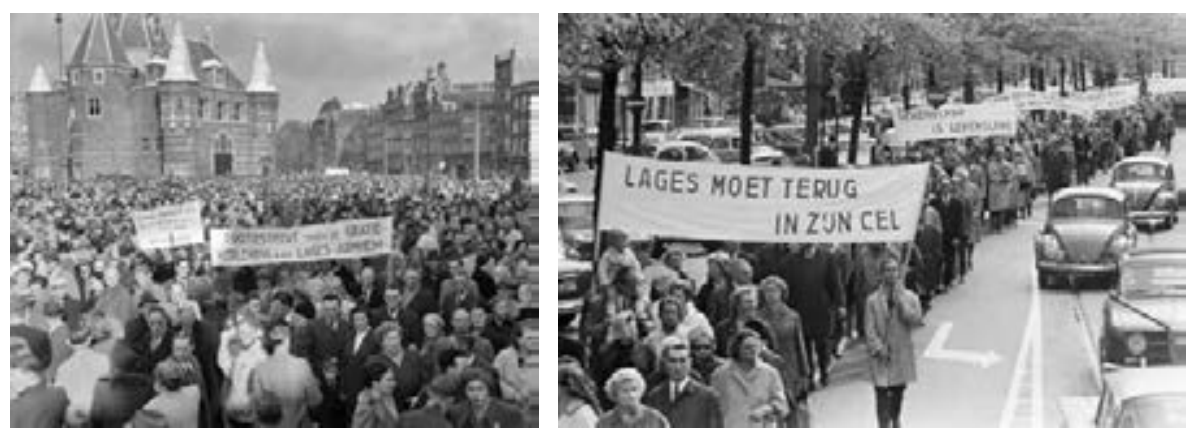

Figure 10.11: Public protests in 1952 and 1966 against the leniency shown to Lages and, by implication, Fischer and Aus der Fünten. Wikipedia.

Amsterdam, $12^{\text {th }}$ October 1952 Amsterdam, $18^{\text {th }}$ September 1966

Public protest against the pardoning of Willy Lages by Queen Juliana.

Public protest against the release of Willy Lages by Justice Minister Samkalden (PvdA); "Terug in zijn cel" ("Back in his cell").

fighters. He personally attended the execution of Johannes Post of the Rijnsburg resistance group on $16^{\text {th }}$ July 1944 (see the story of Sara Philipson and the death of de Groot, below). He was sentenced to death in 1949, and again in the Court of Appeal in 1950. He was pardoned by Queen Juliana against the express wishes of the cabinet. Although the war had not yet received much public attention at this time, the pardon resulted in public protests (Fig. 10.11, left). He was also incarcerated in Breda. He was released in 1966 because he was assumed to be terminally ill, but he recovered while in Germany, where he lived for another five years. His release by Minister of Justice Ivo Samkalden (Labour Party, Partij van de Arbeid) caused public outcry yet again (Fig. 10.11, right). Years later the proposal (1972) by Minister of Justice Dries van Agt, of the Catholic People's Party, to release the three remaining German prisoners (Fischer, Aus der Fünten, and Joseph Kotälla, the "butcher" of Camp Amersfoort) again caused such a public uproar that the proposal was withdrawn. Kotälla died in prison in 1979. The other two were released in 1989, when it was certain that they were on the brink of death. Together, the four and after the release of Lages, the "Breda Three" (Piersma, 2005) dominated public discussion for many years. ${ }^{15}$

Albert Konrad Gemmeker was Kommandant of Camp Westerbork from $12^{\text {th }}$ October 1942 to April 1945. He must have been known to everybody on the list at the back of this book who passed through Camp Westerbork after $12^{\text {th }}$ October 1942

15 From many post-war interviews it is clear that Minister of Justice van Agt never understood why there was such extraordinary opposition against his 1972 proposal to release them. The Dutch refusal to release them caused protests in Germany during Queen Juliana's state visit in November 1971. The protesters generally refused to accept that they were war criminals of the worst kind, calling them "prisoners of war" instead. 
when he took command. Compared to the brutality of his two German predecessors, his regime seemed to be a relief. He realized that behaving as a "gentleman" was a much more clever and effective way to preserve the deception about the "labour camps" and keep the prisoners hushed. He maintained a relatively polite and sometimes courteous attitude to the inmates; he did not show any violence or brutality such as was normally ingrained in the SS. He allowed all necessary social services (hospital, dentists, a school, kindergarten, library, sports activities) to be organized by those inmates who were not immediately sent "through" to the East. Most impressive was the regular performance of a cabaret (rather a "revue"). Gemmeker always attended, laughed abundantly, but never applauded (van Liempt, 2019). It was a highly successful and very hideous tactic: under his command more than 80,00o Jews were exported from Holland to various death camps without any significant disturbance. Behind the gentlemanlike façade lurked a compulsory urge to please his superiors, and, above all, meet the weekly target number of Jews to be deported. He was super-sensitive to any real or perceived lack of respect from his prisoners. For an offense like not removing a hat in a timely fashion when Gemmeker passed by, or not applying a garden rake energetically enough, a prisoner could find himself on the list for the next transport: a death sentence.

After the war, Gemmeker claimed that he never knew what was happening with the people he put on the trains, and he maintained that claim until his death in 1989. It is impossible to believe that he, a senior SS officer, getting his instructions from Eichmann in Berlin via Zöpf and Harster in The Hague, would not have known what was being done to the Jews when they arrived in the East. He was also personally present in Apeldoorn on $22^{\text {nd }}$ January 1943 when more than a thousand mental patients were brutally thrown into a train, which went straight to Auschwitz to prevent unrest in Westerbork, and surely, he knew that the patients were not going to any "labour camp". But post-war prosecution was, so it seems, unable to find enough documentary evidence to convict Gemmeker, and no doubt his non-brutal behaviour in Westerbork also helped him to dodge the death penalty. He was convicted in 1949 and sentenced to ten years imprisonment, but he was released on $20^{\text {th }}$ April 1951, about two years later, pardoned by Queen Juliana on the recommendation of Minister of Justice Johan van Maarseveen, of the Catholic People's Party. Thus, he spent six years in prison, including the preconviction period, about 40 minutes for each man, women and child who perished after being deported from Westerbork under his direction. The post-war German Justice Office investigated the possibility of putting Gemmeker on trial again, following the trials of Harster and Zöpf, without success. Gemmeker successfully escaped justice again, but not without an exceptional degree of good luck (van Liempt, 2019). 

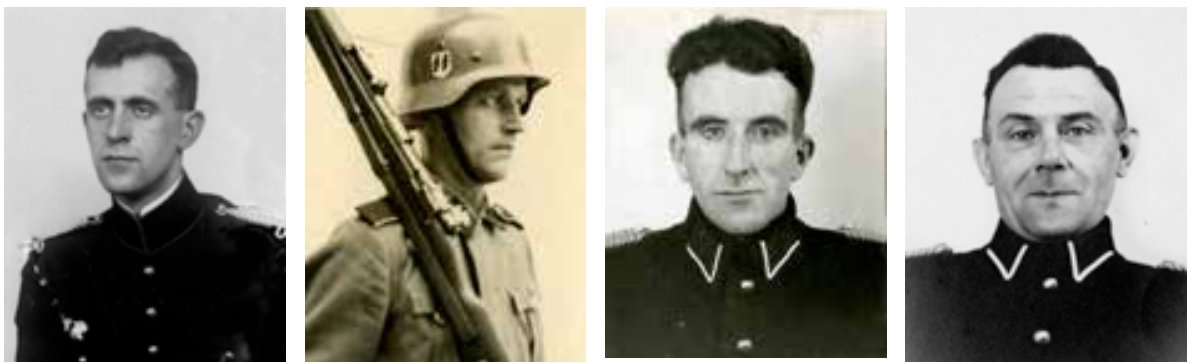

Figure 10.12: The main Dutch perpetrators in the context of this book. Photos courtesy Nationaal Archief/ CABR, The Hague.

Steven van Musscher as Dutch police officer and in uniform of the Waffen-SS. Fled in April 1945 to

Germany, which refused to extradite him. Died 2003. Served c. 9 years.
Adrianus Biesheuvel (1909-1986)
Willem de Groot Shot dead by Dutch resistance 1944 at the onderduik address of Sara Philipson in Rijnsburg.

Like the four Germans in Figure 10.10, the three Dutchmen in Figure 10.12 were most actively involved with the deportation of the Jewish inhabitants of Leiden, including the inhabitants of the orphanage.

Steven van Musscher was in charge of the Leiden police squad which arrested 59 people in the orphanage on $17^{\text {th }}$ March 1973 and despatched them by train to Westerbork. He was a former naval officer who sympathized with the Germans and became a member of the NSB in October 1940. Later, he joined the WaffenSS and followed the Nazi indoctrination course in Avegoor (Fig. 10.12). He was appointed to the Leiden police force on $15^{\text {th }}$ August 1941, ostensibly to replace people who were considered disloyal to the German authorities. He was well educated, completed higher secondary education (HBS-B) and a merchant naval college before receiving his commission as a navy officer in 1937. He had no patience for unprofessional behaviour, irrespective of any political affiliation. He wrote a damning "character" report (21 ${ }^{\text {st }}$ January 1944) about commissioner Ulrich Hoffmann, who had been his superior officer in Leiden, and who was a fellow NSB member. ${ }^{16}$

16 Van Musscher was asked by his superiors in the Nazi organization to comment on Hoffmann's application to be admitted as "begunstigend lid" of the "Germaanse SS". Van Musscher advised against it. He thought Hoffmann was an entirely unreliable character, prepared to do anything in his own interest. He quotes examples: Hoffmann infiltrated successfully into a student resistance group by giving his word that his informant would not be harmed. He had him arrested nevertheless. He entertained an amorous relation with another student, and had her arrested as well after she became pregnant. He also used his position for personal gain. I suspect that his education at the naval academy shaped his belief in a code of honour. Nevertheless, he faithfully executed orders from the German and Dutch authorities to arrest and deport Jews. Letter in Dossier van Musscher. 
He was promoted to chief of police in Gouda on $1^{\text {st }}$ April 1944 and received a commission as Oberleutnant with the Ordnungspolizei in Rotterdam. ${ }^{17}$ In line with his behaviour in Leiden, he proved to be a zealous administrator who demanded strict and proper behaviour and discipline from his subordinates, and he was used to exercising authority. He put an end to the practice of municipal civil servants in Gouda of giving direct instructions to police officers. He was afraid that the Gouda police station would be raided by the resistance. In May 1944 he instructed his staff to keep the station entrance locked at all times and to ensure that whoever opened the door was covered from behind by a colleague with a drawn loaded handgun. During Operation Market Garden in September 1944 (the attempt of the allies to cross the major rivers and canals between liberated Belgium and Arnhem), when people expected the whole of the Netherlands to be freed from the Germans, van Musscher told his wife and daughter to move to Germany, while he stayed in Gouda. He wrote to her about his transfer to Rotterdam and to a training camp near Munich, which he attended. In February 1945 he told her that he might be transferred to the Eastern Front.

On $10^{\text {th }}$ May 1945, four days after liberation, van Musscher was suspended from his police commission on suspicion of collaboration with the Germans. No address was given on the document: he had escaped to Germany weeks earlier, realizing how his wartime activities would be judged after the war. He probably knew that his membership of the Waffen-SS entitled him to German nationality. He would not have known, but probably counted on, any future German government not being willing to extradite German nationals. Indeed, several attempts by the Dutch Justice Department to have him extradited failed. Twenty years after the war, the public prosecutor in Rotterdam instructed the police commissioner in Gouda (van Musscher's last domicile in Holland) to maintain him on the wanted list (police records, Gouda, $23^{\text {rd }}$ March 1965). But the (West) German government continued to protect him until his death in 2003.

Adrianus Biesheuvel and Willem de Groot probably formed the most notorious duo of Jew hunters in the Leiden police force. They worked in a special unit, the Documentatiedienst, within the police force, dedicated to political and sensitive tasks. They were dedicated "Jew hunters" in the sense of van Liempt (2005). Biesheuvel was present at the liquidation of the orphanage on $17^{\text {th }}$ March 1943. It is not known if de Groot (the duo operated mostly together) was also at the orphanage or whether he was hunting Jews elsewhere in Leiden that day. In this period the duo was engaged full-time with arresting Jews (some still lived at their official addresses) and hunting those who had gone into hiding. After spending one or more nights in a police cell in Leiden, most of them were delivered to 
the SiPo in The Hague. They duly reported their successful arrests in the police records, often signing their report by name, or "Documentatie Dienst". Analysis of these archives (Kasteleyn, 2003, and personal communication) shows that the two men arrested 76 Jews without doubt, and probably 127 all together in the ten months they worked together. ${ }^{18}$ On Wednesday, $23^{\text {rd }}$ June 1943 , just before midnight, they arrested five people at Oude Rijn no. 48, including Jacob Philipson, his parents-in-law ${ }^{19}$ and the man who gave them shelter. Five days later the "catch of the week", some fifteen people (including at least four men who had sheltered the onderduikers) were delivered to the German police (presumably in The Hague or Rotterdam).

The duo made many more arrests, as a duo or on an individual basis, and not only in Leiden and its surrounding villages, but also in other places. On $31^{\text {st }}$ July 1943 Biesheuvel records the arrest that day, in Amsterdam, of Robert I. de Groot. He also arrests Frederik Kerkhoven, who harboured Robert at his home. He duly records the "legal" basis for these arrests: Robert for having moved to a new address as a Jew without permission, and Kerkhoven for having provided shelter to a Jew who had committed a criminal offense. Both spent six nights in a cell in the Leiden police station before being handed over to the Germans. I don't know (yet) what happened to Kerkhoven. ${ }^{20}$ Robert de Groot, "Robbie", was killed in Auschwitz on $6^{\text {th }}$ November 1943. He was six years old.

Willem de Groot was shot by a member of the Johannes Post resistance group on Monday, $17^{\text {th }}$ January 1944, during their raid on the house of Piet "Sik" van Egmond in Rijnsburg, the onderduik address of Sarah Philipson. It has been assumed that she was betrayed, but no specific evidence for that has yet come to light. Rijnsburg was a tight community with a large number of Jewish onderduikers (de Beer, 2015). A few "unreliable" characters, including one NSB member, were warned that they would be killed if they spoke a word to the police or the Germans. De Groot and Biesheuvel must have had suspicions about this village but had not been able to make any arrests. It is possible that they were attracted to this house by the underground activities of van Egmond and his many co-workers. Rita Klein was also in hiding in Rijnsburg, delivered by Emilie Stoffels. She stayed with another Van Egmond family.

The above-mentioned police reports were available to the courts after the war. But as time passed the sentences became less severe. Biesheuvel was sentenced in December 1948 to thirteen years in prison. A request for pardoning by his parents

18 Between Biesheuvel's arrival at the Leiden police force on $1^{\text {st }}$ March 1943 and de Groot being killed on $17^{\text {th }}$ January 1944 .

19 Jacob Simons and Sara Simons-Soosman.

20 He is not listed in databases in Holland or Yad Vashem 
was declined in August 1951. He was released in 1954, after serving seven years. De Groot was posthumously stripped of his pension rights in February 1948, leaving his wife, who was in poor health, and her two children in destitution. She wrote a letter to (then Crown Princess) Juliana acknowledging her husband's role in hunting Jews but asking her not to punish her and the children for his acts. She had been openly supportive of the Nazi regime and her request was denied. Later, the children's pension rights as orphans were restored.

There were more members of the Leiden police force who collaborated with the Germans to varying degrees. Stoffels wanted some 20 of them to be prosecuted or at least investigated in 1945. No part of the research underlying this book was more depressing than reading the dossiers of the Special Tribunals $\left(\mathrm{CABR}^{21}\right)$ in the National Archives (see van Liempt \& Kompagnie, 2013). The cool, matter-of-fact reports in the archives of the Leiden police force (Kasteleyn, 2003) about arresting people and handing them over to the Germans are equally depressing.

Yet this study has also bought to light small but significant acts of defiance by people who never sought recognition for what they did. Van Musscher himself reports that two of his colleagues in the police force visited De Sitterlaan 94 early in the morning of $17^{\text {th }}$ March 1943 to warn the Jews in hiding there that they would be arrested later that day. I do not know who the onderduikers were (the address is not listed by Siebelt 2011b) or the police officers.

There can be little doubt that the few selected people in Chapter 10.3 were heroes, and those in this chapter (10.4) were not, but evaluating the behaviour of the vast majority of people who were neither, the "bystanders", remains controversial to this day. The German occupation has had a formidable and lasting impact on Dutch society. The question of "good and bad" dominated post-war historiography (Herzberg, 1985; Presser, 1965; de Jong, 1969-1994). It was hardly possible to do historical research without causing emotional and politically charged debates and personal attacks on authors. In the 1980 s, Blom argued that the time had come to analyze the history of the occupation with a little more "distance", looking for possible alternative methods of research which would not be controlled and restrained by the moralizing framework of "good and bad" (Blom, 1986). Some 20 years later he concluded that academic research had indeed made significant progress in this direction, but that the public debate remained within the good vs bad framework as strongly as ever before (Blom, 2007).

21 Some 130,000 individuals were investigated by these post-war tribunals for possible collaborations with the Germans (not only with respect to the persecution of Jews). 

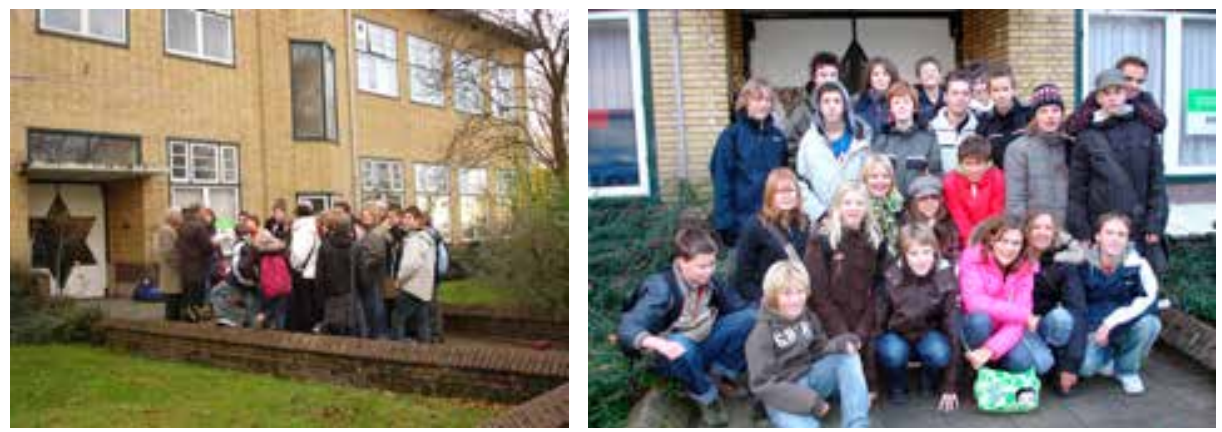

Figure 10.13: 14th November 2007; Students of the Erasmus College in Zoetermeer held a first memorial service at the erstwhile orphanage. A new group of students came over to Leiden every year to read out the names, until Corona halted the tradition in 2020.

\subsection{The next generation}

The text from Deuteronomy quoted at the beginning of this book admonishes us not just to remember "what our eyes have seen" but to pass it on to our children and grandchildren. Indeed, to retrieve and preserve the names and the memory of the murdered children would be rather futile if we cannot pass on the memory to next generations.

Every year, on or around $17^{\text {th }}$ March, students from a secondary school in Zoetermeer hold a memorial service at the orphanage (Fig. 10.13). To date thirteen "generations" of students have taken part in the ceremony. After visiting the Leiden synagogue for an introduction ${ }^{22}$ to Jewish religion and culture, the story of Esther is told, since the ceremony takes place around mid-March, close to Purim, and in memory of the fact that the group from Leiden celebrated Purim three days after their arrival in Westerbork, and just before the first group was deported to Sobibor. After listening to Merlyn Frank's lecture (Ch. 10.2), they walk to the former orphanage along the route shown in Figure 4.9. After a short introduction about what happened on $17^{\text {th }}$ March, the students read out the names of the 55 children and staff who were forcefully removed from the building that night (Table 7.1) and who did not return from deportation.

The Jewish orphanage in Leiden never reopened. In fact, most orphanages, and many other Jewish social institutions in Holland (van der Eerden, 2014; Staal, 2008, 2015) had been destroyed beyond recovery: the communities they were meant to serve no longer existed. Some institutions, such as the boys' orphanage (Megadlé 
Jethomim) on the Amstel (in 1947 it moved to Emmalaan 7 in Amsterdam ${ }^{23}$ ), and the Bergstichting in Laren, served as a home for children who survived the Holocaust for a limited time. Jacob Brilleman reports (postcard to Hijme Stoffels, $25^{\text {th }}$ July 1945) that they had go children in Laren. The Bergstichting (van der Eerden, 2014) closed its doors in the 196os. The orphanage on the Amstel was demolished in 1977, with practically all the remaining derelict houses of the former Jewish Quarter. But the orphanage building in Leiden still stands. The Leiden synagogue was ransacked inside, but it was restored after the war. However, the pre-war Jewish community never recovered and regular services cannot be held anymore.

The fact that the two buildings have survived has been important to the successful holding of the ceremony over the years. So has the fact that the names of the children who lived there are known, and that there are photographs to show and stories to tell. The Holocaust does not lend itself to romanticized fantasy stories or theatre films. The students always ask whether what we tell them has actually happened. According to Mr. Hans Wolf, who was their history teacher for most of these years, it is the reading aloud of the names of the individuals and knowing something about each of them what makes the strongest impression on the students. That is a moving observation.

The orphanage building in Leiden was sold to the government after the war and the proceeds were used in part to build Beth Juliana in Israel. It had many different occupants after the war. Seemingly Elchanan Italie was one of the first after liberation (Ch. 9.9). It served as a temporary "openbare" (public) school with eleven classrooms until new buildings were ready in $1959,{ }^{24}$ after which the GG\&GD (municipal health service) moved in. The building currently serves as a medical centre.

I hope that the building, which externally is still in its original shape, might someday become a municipal monument, because of its historical and its architectural significance. But not before the horrid post-war extensions along the Cronesteinkade have been removed, and the unique back side of the building (Fig. 3.6) can be seen again from the street. Any such plan could also consider including the houses on the opposite side of the Roodenburgerstraat at the corner with the Cronesteinkade, which were built in the same style as the orphanage.

23 Niek van Zutphen, "Het Joodse Jongensweeshuis in de Emmalaan, 1947-1965", in Ons Amsterdam, $18^{\text {th }}$ May 2014, https://onsamsterdam.nl/. It closed in 1965

24 The new school was built on Oppenheimerstraat, as was the Catholic St. Joseph School. Both schools were inaugurated at the same time (Leids Dagblad, $13^{\text {th }}$ June 1959). 


\section{References}

Beer, W. de, et al., 2015; "Een veilig nest voorvervolgden. Verhalen over Joodse onderduikers in Rijnsburg”. Genootschap Oud Rijnsburg. [A collection of stories about the many Jewish onderduikers (including Sara Philipson and Rita Klein) who found shelter in this small strictly reformed Christian village in the Leiden area. The stories are included as they were told, without being checked against other sources or documents.]

Blom, J.C.H., 1986; "In de ban van goed en fout? Wetenschappelijke geschiedschrijving over de bezettingstijd in Nederland". In: Abma et al., 1986 , pp. 30-52.

Blom, J.C.H., 2007; "In de ban van goed en fout. Geschiedschrijving over de bezettingstijd in Nederland”. Amsterdam, Boom, ISBN 9789085064633.

Bossenbroek, Martin, 2001; “De meelstreep. Terugkeer en opvang na de Tweede Wereldoorlog”. Amsterdam, Bert Bakker, ISBN 905123697.

Buruma, Ian, 2013; "Year zero: A history of 1945”. London, Atlantic Books, ISBN 9781848879379/373.

Eerden, E. van der, 2014; "De Berg-Stichting: 'oase in harde en desillusioneerende maatschappij'”. Contactblad '40-45, pp. 4-7. ISSN 1569-1209.

Frank, Merlyn, 1998; “Koosje. Een dinsdagkind”. Schoorl, Conserve, ISBN 9054290927.

Herzberg, A.J., 1985; “Kroniek der Jodenvervolging, 1940-1945”. Amsterdam, Querido, ISBN 9021465779. First published in 1950.

Jong, L. de, 1969-1994; “Het Koninkrijk der Nederlanden in de Tweede Wereldoorlog”. http:// www.dbnl.org or http://www.loedejongdigitaal.nl/. [The standard (contemporary) history of the Netherlands during the war. The entire text is available online (with search facility). For more recent interpretations, see Blom et al., 2021.]

Kasteleyn, L.P., 2003; "Vervolging en bescherming, joden in Leiden 1933-1945”. Leiden, Museum de Lakenhal.

Kopuit, M., 1974; “Groot boeren- en kaasbedrijfvan oud-Leidenaars in Beth Jitschak” [Dairy farm of Ben Meijer and family]. Nieuw Israëlitisch Weekblad, 11 January, p .7.

Liempt, A. van, 2005; “Hitler's bounty hunters: The betrayal of the Jews". New York, Berg, ISBN 1845202031/9781845202033.

Liempt, A. van, 2019; “Gemmeker. Commandant van Kamp Westerbork”. Amsterdam, Balans, ISBN 9789460039782 (hardcover)/9789460039799 (ebook).

Liempt, A. van \& J. Kompagnie (eds), 2013; "Jodenjacht: de onthutsende rolvan de Nederlandse politie in de Tweede Wereldoorlog" [Hunting down Jews: The shocking role of the local Dutch police during the German occupation], $5^{\text {th }}$ ed. Amsterdam, Balans, ISBN 9789460037221.

Michman, Jozeph \& Bert Jan Flim (eds), 2004; "The encyclopaedia of the righteous among the nations: Rescuers ofJew during the Holocaust. Volume: The Netherlands". Jerusalem, Yad Vashem.

Michman, Jozeph, Hartog Beem \& Dan Michman, 1999; "Pinkas. Geschiedenis van de joodse gemeenschap in Nederland". Incorporating research by Victor Brilleman. Amsterdam, Uitgeverij Contact \& NIK, ISBN 9025495133. [The original text of this comprehensive 
history of the Jews in the Netherlands is also available in Hebrew, Yad Vashem, Holocaust Martyrs' and Heroes Remembrance Authority, Jerusalem, 1985.]

Piersma, Hinke, 2005; "De drie van Breda. Duitse oorlogsmisdadigers in Nederlandse gevangenschap 1945-1989". Amsterdam, Balans, ISBN 9050186610/9789050186612.

Presser, J., 1965; "Ondergang. De vervolging en verdelging van het Nederlandse Jodendom, 1940-1945". 's-Gravenhage, Staatsuitgeverij/Martinus Nijhoff. [The entire Dutch text is available online (with search facility) at http://www.dbnl.org. Although written more than half a century ago, the book is still very readable and impressive today.] An English translation was published by E.P. Dutton \& Co. in 1969 (ASIN BoooLD8D7S), and again in 1988 under the title "Ashes in the wind: The destruction of Dutch Jewry" by Wayne State University Press; re-issued in 2010, ISBN 9780285638136.

Rose, Leesha, 1978; “The tulips are red”. South Brunswick, Barnes \& Co., ISBN 0498021769. [Leesha Rose (Bornstein during the war) collaborated in the resistance with van Wijk and Stoffels.] Schelvis, Jules, 2007a; "Binnen de poorten. Een verslag van twee jaar Duitse vernietigings- en concentratiekampen”. Amsterdam, De Bataafse Leeuw, ISBN 978906707626. [Schelvis is one of the 18 survivors of the 34,314 people deported from Westerbork to Sobibor. This is his own account of his deportation and survival.]

Siebelt, Alphons, 2011b; "Gids voor Leiden in de Tweede Wereldoorlog. Beschreven in $65^{\circ}$ adressen" [Guide to Leiden in the Second World War, described in $65^{\circ}$ addresses]. Leiden, Ginkgo.

Siebelt, Alphons, 2015; "Hij zit bij de onderduikersbond. Hulp aan Leidse onderduikers in de Tweede Wereldoorlog". Leiden, Primavera Press. [A study of the organized assistance to onderduikers in Leiden, arguably the most important form of resistance during the occupation of the Netherlands, where armed resistance was virtually impossible for the lack of wilderness areas where partisans could hide.]

Staal, Philip, 2008; "Roestvrijstaal. Speurtocht naar de erfenis van Joodse oorlogswezen". Delft, Eburon, ISBN 9789059722712. English edition: Staal, 2015.

Staal, Philip, 2015; "Settling the account (Mijn erfenis)". Bloomington, iUniverse, ISBN $9781491751664 / 51657$.

Stoffels, H. \& E. Stoffels-van Brussel, 1967; “Unpublished", $22^{\text {nd }}$ November. [A list of (some of) their activities in support of Jewish citizens of Leiden from February 1942, such as arranging onderduik addresses, false papers, etc. The list was written at the request of Elchanan Italie, in support of a proposal by him and the family Philipson-Armon to award the Yad Vashem award to Stoffels and his wife.

Wijk, Cor van, 1946; "Mijn werk in de Nederlandse Verzetsorganisatie 'Strijdend Nederland'”. Typescript, Regionaal Archief Leiden (now Erfgoed Leiden \& Omgeving). [An account of his wartime activities, including the provision of (at least) 420 blank but genuine pb's to the Leiden underground movement. No less than 124 of these were used by Stoffels.]

Withuis, Jolande, 2013; “Weest manlijk, zijt sterk. Pim Boellaard (1903-2001) Het leven van een verzetsheld”. Amsterdam, De Bezige Bij, ISBN 9789023478430. 
